\title{
Brian Williams and the Perils of the Use of Autobiographical Memory in Research
}

\section{West MD*}

Mass Communication Department, University of North Carolina at Asheville, NC 28801, USA

\begin{abstract}
Brian Williams, an American journalist who had for ten years served as anchor and managing editor of NBC Nightly News was recently suspended for six months for "misrepresent[ing]" events which he claimed occurred during his coverage of the Iraq War in 2003. While many have questioned why Williams, a well-known and widely respected broadcast journalist, would have fabricated the degree of risk he faced in his war coverage, few have considered that he might have unwittingly, rather than deliberately, misrepresented events in the past. Autobiographical memory, however, is highly susceptible to a variety of influences which can create false memories. While researchers have, for obvious reasons, created benign memories, cases exist in which individuals have been tried for crimes which in retrospect seem ludicrous. I argue that, whatever the reason for Brian Williams' exaggeration of the level of threat which he faced in Iraq in 2003, the implications of such exaggerations for communication research are sobering.
\end{abstract}

\section{Keywords: Autobiographical; Brain; Memory}

\section{Brian Williams and the Inflation of Memory}

Brian Williams, an American journalist who has for ten years served as anchor and managing editor of NBC Nightly News, was recently suspended for six months for "misrepresent[ing]" events which he claimed occurred during his coverage of the Iraq War in 2003. While many have questioned why Williams, a well-known and widely respected broadcast journalist, would have fabricated the degree of risk he faced in his war coverage, few have considered that he might have unwittingly, rather than deliberately, misrepresented events in the past. Williams' original March 26, 2003 report from Iraq indicated that the helicopter in front of his as they approach a landing point was hit, something that Williams learned once he and his crew landed. But the book published that September under the imprimatur of NBC implied that the helicopter in which the NBC team flew was flying was hit by enemy fire. The book, entitled Operation Iraqi Freedom: Twenty-two historic days in words and pictures and authored by William Arkin, says that Williams ended up on the receiving end of an ambush directed at the 3rd Infantry Division. An army helicopter armada was delivering 17,000-lb. sections of a platoon bridge to Najaf, about 100 miles south of Baghdad. The NBC team went along for the ride, occupying the third of four Chinook choppers ... The grenade entered the helicopter's open tail, tore a hole in the fuselage, and grazed acrewman's face, but did not detonate [1]. It was not until 2008 that Williams himself said that he himself was in the helicopter which was struck, which he said in a blog posting; which he said once again in a 2013 interview with David Letterman. On Jan. 30, 2015, Williams retold the story in the process of praising the bravery of the troops in combat; during this conversation, he described his helicopter as having been shot down by RPG fire. The pilot of the helicopter upon which Williams flew posted on Williams' NBC Facebook page on January 31, contradicting his story, and on Feb. 4, 2014, Williams apologized for his exaggeration:

I want to apologize. I said I was traveling in an aircraft that was hit by RPG fire. I was instead in a following aircraft. We all landed after the ground fire incident and spent two harrowing nights in a sandstorm in the Iraqi desert. This was a bungled attempt by me to thank one special veteran and by extension our brave military men and women, veterans everywhere, those who have served while I did not. I hope they know they have my greatest respect, and also now my apology. The exaggeration raised considerable controversy about Williams' credibility, and NBC soon informed staffers that Williams would be removed from the Nightly News for a time on Feb. 10 [2].

Williams later, in an interview with Stars and Stripes, spoke of the fear which he felt when the helicopter he was riding landed abruptly. No, I think I correctly reported as I did in my blog in '08 that I was on the aircraft behind the one that was hit. It was not... Because I knew we had all come under fire, I guess I had assumed that all of the airframes took some damage because we all went down. Also, remember, adding to the fear of the moment was the fact that we unhooked, our load master let loose a huge, our cargo, so you go through this over-torque where you rise in the air before you settle, despite what was some dandy piloting by the crews of all three aircraft. It was like landing on the surface of the moon. And I'm going to have a far different recollection than the professionals. These are the guys, and I think maybe you know more than I do - Was it a mixture of Big Windy [Company] out of Germany and Air National Guard from the States? Because that is what I recall [3].

The interviewer then tells Williams that his helicopter was in a second grouping of helicopters, distinct from the first group, which contained the helicopter which was struck by an RPG. To this, Williams responds: And that's the first I've heard of that. I did not think we were in trail by that far. I think that's probably a good question for Tim, who I now learn witnessed the overflight. But I could not see in front of us and I thought we were just in one flotilla, for lack of a better word. That's the first time I've heard that [3].

To hear Williams tell his side of the story, he appears to be confused about the position of his helicopter in the flight and to have been frightened by the maneuvers of the craft. Commentators, however,

*Corresponding author: West MD, Mass Communication Department University of North Carolina at Asheville, NC 28801, USA, Tel: 828-232-5027 E-mail: westinbrevard@yahoo.com

Received March 19, 2015; Accepted April 13, 2015; Published April 23, 2015

Citation: West MD (2015) Brian Williams and the Perils of the Use of Autobiographical Memory in Research. J Mass Communicat Journalism 5: 255. doi:10.4172/2165-7912.1000255

Copyright: ( 2015 West MD. This is an open-access article distributed under the terms of the Creative Commons Attribution License, which permits unrestricted use, distribution, and reproduction in any medium, provided the original author and source are credited. 
have been merciless, generally following the lead of Dave Helling at the Kansas City Star:

Public figures, it turns out, are rarely challenged in public. That can leave them believing their own myths at the expense of reality.

"People who are in the public eye ... think they're above it," said Jeffrey Walczyk, a psychology professor at Louisiana Tech University and a student of human deception for more than a decade.

"It's possible (Williams) didn't lie, in the sense that he came to believe what he had said," Walczyk said. "But he probably thought no one would fact-check, or he believed he could get away with it" [4].

\section{False Memories}

As suggested in the above quotation, the Williams case has been widely accepted as one in which Williams inflated the danger he faced for personal reasons (to inflate his reputation) or economic reasons (to inflate the ratings of NBC's Nightly News) [5]. Little attention has been paid to the alternative possibility that Walczyk raised in Helling's column - that Williams "came to believe what he had said."

Research suggests, however, that autobiographical memory is highly susceptible to a variety of influences which can create false memories. While researchers have, for obvious reasons, created only benign memories, numerous cases exist in which individuals have been tried for crimes based on false memories which were created through the interviewing techniques employed by parents and police.

In many cases, the events which are described by accusers in retrospect seem ludicrous. In the accusations in the McMartin Preschool case in California in 1983, the case began when Judy Johnson accused Ray Buckey, an aide at the school, of flying through the air and bizarre forms of physical abuse; her young son confirmed those allegations [6,7]. She then accused Peggy Buckey, Ray's mother, of various 'satanic' practices. Her son was said to have seen a rabbit being chopped up and a baby being beheaded; the boy was forced to drink the blood of the baby, which the boy confirmed in interviewing [8].

In the McMartin Preschool case, the striking event is not that the accusations of Johnson, who was later confined as a paranoid schizophrenic, were investigated; it was that the young witnesses confirmed them and added details [9]. After the case was closed with no convictions, the interviewing techniques used on the children were found to generate false memories in children with no relation to the McMartin case [10].

Such interviewing techniques have been found in empirical research to have the potential to cause false memories in both children and adults. College students were interviewed about an accident that purportedly occurred at a family wedding, which they later 'recalled' as having occurred; and preschoolers were asked to think about having had their hand trapped in a mousetrap and having to go to the hospital to have it removed; they later recollected that event as having actually happened $[11,12]$. One-quarter of respondents were convinced that, as children, they had been lost in a shopping mall when such an event had never occurred [13]. As Loftus suggests, if family members suggest to subjects that they saw the event being suggested, it is possible to convince even adult subjects that they in the past had extended experiences including hospitalizations, being lost, or of undergoing embarrassing experiences at familial events [14].

Sometimes the false memories can be elaborate, as in the case of a story related by Loftus and Ketcham [15]:
One of my first memories would date, if it were true, from my second year. I can still see the following scene, in which I believed until I was about fifteen. I was sitting in my pram, which my nurse was pushing in the Champs Elysees, when a man tried to kidnap me. I was held in the strap fastened about me while my nurse bravely tried to stand between me and the thief. She received various scratches, and I can still see vaguely those on her face. Then a crowd gathered, a policeman with a short cloak and a white baton came up, and the man took to his heels. I can still see the whole scene, and can even place it near the tube station. When I was about fifteen, my parents received a letter from my former nurse saying she had been converted to the Salvation Army. She wanted to confess her past faults, and in particular to return the watch she had been given as a reward on this occasion. She had made up the whole story, faking the scratches. I, therefore, must have heard, as a child, the account of the story, which my parents believed, and projected into the past in the form of a visual memory.

Research has suggested that the relative ease of introducing false memories is due to the misinformation effect, when the recall of memories becomes less accurate because of information introduced post-event information. More recent information, in general, is easier to access than more distant, and this general effect, combined with suggestibility and with misattribution (the tendency to define the source of a memory as the self rather than some other entity) combine to create the phenomenon of false memories [16].

\section{Memory as Constructed and Naïve Realism}

From research such as the above, researchers have drawn the conclusion that memories are constructed rather than drawn from some sort of 'memory bank' in the brain. Individuals construct their past on the basis of some few images they retain, plus general knowledge they possess and the social demands which are made upon them at the moment of the situation in which they have to create their memories [17].

Amongst other things, beliefs about how memories are made, narratives and stories, and individual levels of suggestibility play a role in how memories are constructed, as well as the social demands present at the moment when the autobiographical memories are demanded [18-21].

Unfortunately for Brian Williams, most viewers of NBC's Nightly News are naïve realists. Naïve realism is the belief that we see reality as it really is, without bias and as others see it unless they have some sort of bias or irrational approach. Others who disagree with us are uninformed or malicious, and, when presented with the simple objective evidence that is manifest to all objective observers (such as ourselves), will agree unless biased, irrational or lazy [22]. Such a viewpoint, of course, means that individuals whose understanding of the world differs from that held by one's self can only be viewed as 'biased, irrational or lazy,' and serves as a significant impediment to tolerant behaviors of many sorts, leading to substantive misunderstandings in human relations, and significant (and often negative) outcomes in everyday life [2325]. In particular, naive realists have a peculiar relation to memory; an individual is morally responsible for their memory, since memories are attestation of past facts, relating a memory which turns out to be inaccurate is to tell a lie - and hence to commit a blameworthy act.

Things would be bad enough if it were only the case if naïve realism led to the disruption of human relations and a variety of intolerant behaviors; but the judicial system of the United States relies upon eyewitness testimony. Our judicial system, in turn, is itself dependent upon a sort of naïve realism; its reliance upon testimonies based upon 
memory is a major problem $[15,26,27]$. Eyewitness testimony, far from being reliable, is the primary source of wrongful convictions in the United States [28]. As seen in the aftermath of the McMartin Preschool trial, there is a general acceptance by psychiatric professionals of the unreliability of many types of eyewitness testimony, of the effects of question repetition in the formation of false memories, and of questions concerning even the most direct sorts of eyewitness testimony - yet, as Loftus suggests, eyewitness testimony is often taken as the gold standard for testimony in a world in which naive realism is the baseline for folk epistemology [29-31]. Such naïve realism might be seen as a sort of a 'folk epistemology' a la Kitchener, where an individual's view of what we can know and how we come to know it is shaped by social forces $[32,33]$. The act of perception and memory, conceptualized as unproblematic, as Hardy-Vallée and Dubreuil suggest, is the basis for 'normative social cognition,' and, as such, is the foundation for what serves as a normal, social understanding of the 'way things are' which is fully supported by the entire legal apparatus of the state [34,35].

\section{Communication Research and Elicited Memories}

For the communication researcher, Brian Williams' hasty departure from NBC's Nightly News is, thus, more than a reminder that the American public expects their newscasters to be more than reliable readers of prepared news copy. Much of communication research depends upon respondents who reliably relate past experiences upon survey instruments to researchers, and such information is often available in no other manner [36]. Much research, for example, comes down to comparing media effects to respondent descriptions of their own media exposure, with such self-reports playing a particularly crucial role in cultivation research [37-40]. Cultivation research, which seeks to link television viewing to perceptions of risk, has proven to be a durable and popular area of research both in the U.S. and other nations, yet its reliance upon historical reports from respondents might give researchers pause [41]. Survey researchers have found that parents, questioned shortly after their children have received vaccines, give responses concerning which diseases for which their children were vaccinated that were little better than chance [42]. As a result of these and other concerns regarding autobiographical memories, survey researchers have offered cautions concerning the use of selfreports in survey research where those reports cannot be confirmed via other means, and, in particular, without the authentication of autobiographical reports [43-45]. But such recommendations have made little headway in the discipline of communication research.

To be clear, cultivation researchers often ask respondents to selfreport television viewing habits; risk researchers often ask respondents to self-report whether or not respondents have faced certain risks in the past. Such queries are precisely requests for autobiographical memories of the sort discussed above, and, as the research presented above suggests, are inherently unreliable unless confirmed via external means.

\section{Conclusions}

We will never know why Brian Williams inflated the danger which he faced in Iraq in 2003. But we might posit an alternative scenario to the image of Williams as engaging in puffery. Williams, who is rumored to have always felt intimidated by his predecessor Tom Brokaw, was faced with a retelling of the 2003 [46]. Iraq story in NBC's own book on the subject, complete with photographs and a narration by Brokaw. His own memories of the emotionally-jarring incident were incoherent, and he adopted the complete and coherent tale of what happened as narrated by his intimidating predecessor, in much the same manner that the young Piaget came to believe that he had almost been kidnapped. With retelling, the false memory became clear in Williams' mind - until it was contradicted in 2015, and Williams found himself the target of both sanction and ridicule. Whether or not this alternative scenario is true or not is unclear. But what is clear is that communication research, particularly cultivation research, has a long history of dependence on respondent autobiographical reports as a primary aspect of its research projects. We should, in the future, make significant efforts to attempt to consider the unreliability of such data before using it as the keystone of statistical models which, in turn, serve as the linchpin of grand theoretical ventures - particularly in light of the fact that ventures such as cultivation theory and research are one of the inputs into the policy-making aspect of the regulation of television programming in the U.S [47].

\section{References}

1. Arkin WM (2003) Operation Iraqi Freedom: Twenty-two historic days in words and pictures. Andrews McMeel Publishing

2. Kaplan D (2015) Timeline shows events leading to NBC suspending Brian Williams, removing his name from 'Nightly News'

3. Tritten T J (2015) In his words: Brian Williams' interview with Stars and Stripes.

4. Helling D (2015) Amid the Brian Williams furor, here's one truth: Tall tales are a common story.

5. Folkenflik D (2015) Brian Williams criticized for exaggerated Iraq story. Broadcast

6. Reinhold R (1990) The longest trial- A post-mortem; collapse of child-abuse case: So much agony for so little. The New York Times 24

7. Eberle P, Eberle S (1993) The abuse of innocence: The McMartin Preschoo trial. Prometheus Books.

8. Schreiber N, Bellah LD, Martinez Y, McLaurin KA, Strok R, et al. (2006) Suggestive interviewing in the McMartin Preschool and Kelly Michaels daycare abuse cases: A case study. Social Influence 1: 16-47.

9. Butler EW, Fukurai H, Dimitrius J, Krooth R (2001) Anatomy of the McMartin child molestation case. University Press of America.

10. Garven S, Wood JM, Malpass RS, Shaw III JS (1998) More than suggestion The effect of interviewing techniques from the McMartin Preschool case. Journal of Applied Psychology 83: 347-359.

11. Hyman IE, Husband TH, Billings FJ (1995) False memories of childhood experiences. Applied Cognitive Psychology 9: 181-197.

12. Ceci SJ, Huffman MLC, Smith E, Loftus EF (1994) Repeatedly thinking about a non-event: Source misattributions among preschoolers. Consciousness and Cognition 3: 388-407

13. Devitt M, Honts C, Loftus EF (1996) The effects of misinformation on memory for complete events. In Proceedings of the 42nd Annual Southwestern Psychological Association Conference. Houston, TX.

14. Loftus EF (1997) Creating childhood memories. Applied Cognitive Psychology 11: S75-S86.

15. Loftus E, Ketcham K (1992) Witness for the defense: The accused, the eyewitness, and the expert who puts memory on trial. Macmillan.

16. Saunders J, MacLeod MD (2002) New evidence on the suggestibility of memory: the role of retrieval-induced forgetting in misinformation effects. Journal of Experimental Psychology: Applied 8: 127.

17. Hyman I E, Loftus EF (1998) Errors in autobiographical memory. Clinical psychology review 18: 933-947.

18. O'Sullivan JT, Howe ML (1995) Metamemory and memory construction. Consciousness and cognition 4: 104-110.

19. Wyer RS, Adaval R, Colcombe SJ (2002) Narrative-based representations of social knowledge: Their construction and use in comprehension, memory, and judgment. Advances in Experimental Social Psychology 34: 131-197.

20. Quas JA, Qin J, Schaaf JM, Goodman GS (1997) Individual differences in children's and adults' suggestibility and false event memory. Learning and Individual Differences 9: 359-390. 
Citation: West MD (2015) Brian Williams and the Perils of the Use of Autobiographical Memory in Research. J Mass Communicat Journalism 5: 255. doi:10.4172/2165-7912.1000255

21. Conway MA, Pleydell-Pearce CW(2000) The construction of autobiographical memories in the self-memory system. Psychological review 107: 261.

22. Ross L, Ward A (1999) Naïve realism in everyday life: Implications for social conflict and misunderstanding. In T. Brown, E. Reed, \& E. Turiel (Eds.) Values and knowledge. Hillsdale, NJ: Lawrence Erlbaum Associates, Inc.

23. Pronin E, Lin DY, Ross $L$ (2002) The bias blind spot: Perceptions of bias in self versus others. Personality and Social Psychology Bulletin 28: 369-381.

24. Ichheiser G (1949) Misunderstandings in human relations: Astudy in false social perception. American Journal of Sociology 55: 70.

25. Ward A, Ross L, Reed E, Turiel E, Brown T (1997) Naive realism in everyday life: Implications for social conflict and misunderstanding. Values and knowledge 103-135.

26. Loftus EF(1975) Leading questions and the eyewitness report. Cognitive psychology 7: 560-572.

27. Loftus EF(1996) Eyewitness testimony. Mass.: Harvard University Press, Cambridge.

28. Clements N (2007) Flipping a coin: A solution for the inherent unreliability of eyewitness identification testimony. Ind. L. Rev 40: 271.

29. Kassin SM, Tubb VA, Hosch HM, Memon A (2001) On the" general acceptance" of eyewitness testimony research: A new survey of the experts. American Psychologist 56: 405

30. Poole DA, White LT (1991) Effects of question repetition on the eyewitness testimony of children and adults. Developmental Psychology 27: 975-986.

31. Loftus EF (1974) Reconstructing memory: The incredible eyewitness. Jurimetrics J 15: 188-193.

32. Kitchener RF (2002) Folk epistemology: An introduction. New ideas in Psychology 20: 89-105

33. Mercier $\mathrm{H}$ (2010) The social origins of folk epistemology. Review of Philosophy and Psychology 1: 499-514.

34. Hardy-Vallée B, Dubreuil B (2010) Folk epistemology as normative social cognition. Review of Philosophy and Psychology 1: 483-498.
35. Heintz C, Taraborelli D (2010) Editorial: Folk epistemology; the cognitive bases of epistemic evaluation. Review of Philosophy and Psychology 1: 477-482.

36. Baldwin W (1999) Information no one else knows: The value of self-report. In Stone AA, Turkkan JS, Bachrach CA, Jobe JB, Kurtzman HS, Cain VS (Eds.) The science of self-report: Implications for research and practice. Psychology Press.

37. Slater MD (2004) Operationalizing and analyzing exposure: The foundation of media effects research. Journalism \& Mass Communication Quarterly 81: 168183.

38. Potter WJ, Chang IC (1990) Television exposure measures and the cultivation hypothesis. Journal of Broadcasting \& Electronic Media 34: 313-333.

39. Potter WJ (1993) Cultivation theory and research. Human Communication Research 19: 564-601.

40. Hetsroni A, Tukachinsky RH (2006) Television-world estimates, real-world estimates, and television viewing: A new scheme for cultivation. Journal of Communication 56: 133-156.

41. Morgan M, Shanahan J (2010) The state of cultivation. Journal of Broadcasting \& Electronic Media 54: 337-355.

42. Tourangeau R (1999) Remembering what happened: Memory errors and survey reports. In Stone AA, Turkkan JS, Bachrach CA, Jobe JB, Kurtzman HS, Cain VS (Eds.) The science of self-report: Implications for research and practice. Psychology Press.

43. Brewer WF (1994) Autobiographical memory and survey research Autobiographical memory and the validity of retrospective reports 11-20.

44. Schwarz N (1999) Self-reports: how the questions shape the answers. American psychologist 54: 93-105.

45. Ross M, Buehler R (1994) On authenticating and using personal recollections. Autobiographical memory and the validity of retrospective reports 55-69.

46. Sherman G (2015) true war stories at nbc news.

47. Cooper CA (1996) Violence on television: Congressional inquiry, public criticism, and industry response: A policy analysis. University Press of America. 